\title{
CORRECTION
}

View Article Online

View Journal I View Issue

Check for updates

Cite this: Chem. Commun., 2020, 56, 10083

DOI: $10.1039 / \mathrm{dOcc} 90352 \mathrm{c}$

rsc.li/chemcomm

\section{Correction: Development of a bidirectional isothermal amplification strategy for the sensitive detection of transcription factors in cancer cells}

\author{
Yan Zhang, ${ }^{a}$ Qing-nan Li, ${ }^{a}$ Dong-xue Xiang, ${ }^{a}$ Kaiyue Zhou, ${ }^{\mathrm{b}}$ Qinfeng $X \mathrm{u}^{\mathrm{b}}$ and \\ Chun-yang Zhang*a
}

Correction for 'Development of a bidirectional isothermal amplification strategy for the sensitive detection of transcription factors in cancer cells' by Yan Zhang et al., Chem. Commun., 2020, 56, 8952-8955, DOI: 10.1039/ DOCC03134H.

We regret that an incorrect version of Fig. 3 was published in the original manuscript. The corrected Fig. 3 is shown below with unchanged legend.
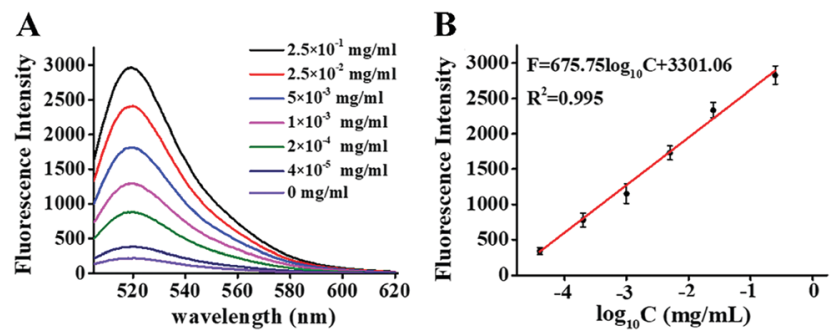

Fig. 3 (A) Fluorescence emission spectra in response to different concentrations of nuclear extracts. (B) Linear relationship between the fluorescence intensity at $521 \mathrm{~nm}$ and the logarithm of nuclear extract concentration in the range from $4 \times 10^{-5}$ to $2.5 \times 10^{-1} \mathrm{mg} \mathrm{mL}^{-1}$. The $500 \mathrm{nM} \mathrm{TF-binding} \mathrm{probes}$ and $20 \mathrm{ng} \mathrm{mL}^{-1}$ TNF-a were used in the experiments. Error bars show the standard deviation of three independent experiments.

The Royal Society of Chemistry apologises for these errors and any consequent inconvenience to authors and readers.

\footnotetext{
${ }^{a}$ College of Chemistry, Chemical Engineering and Materials Science, Collaborative Innovation Center of Functionalized Probes for Chemical Imaging in Universities of Shandong, Key Laboratory of Molecular and Nano Probes, Ministry of Education, Shandong Provincial Key Laboratory of Clean Production of Fine Chemicals, Shandong Normal University, Jinan 250014, China. E-mail: cyzhang@sdnu.edu.cn; Fax: +86 0531-82615258; Tel: +86 0531-86186033

${ }^{b}$ School of Food and Biological Engineering, Shanxi University of Science and Technology, Xi'an 710021, P. R. China
} 